\title{
Building Blocks to Effective and Sustainable University Governance in Uganda
}

\author{
S. Asiimwe and G. M. Steyn* \\ Department of Educational Leadership and Management, University of South Africa, \\ PO Box 392, Pretoria, 0003, South Africa \\ Mobile: 082886 7468, "E-mail: steyngm1@unisa.ac.za
}

KEYWORDS University Governance. Governance Practices. Mixed Methods Research

\begin{abstract}
The issue of university governance has become the subject of intense debate globally, triggering a contest for governance systems that are responsive to the changing demands of university stakeholders. This article focuses on building blocks for effective and sustainable university governance in Uganda and reflects on a section of a doctoral thesis on developing and sustaining effective governance of universities in Uganda. The study utilised a mixed method research approach and investigated governance practices at both public and private universities. It consisted of two phases. Phase 1 was a quantitative design and phase 2 was a qualitative research design. The study explored how universities can build and sustain effective governance. It was concluded that to build and sustain effective university governance, the following building blocks are critical: professional competence of members of the university board, quality governance structures, a participatory planning process and board participation in management. For effective university governance, the study recommended the following: (1) university boards should be composed of members with an appropriate level of professional competence related to university governance (2) universities should create appropriate governance structures where roles are segregated among the various committees to create the necessary checks and balances (3) ownership of plans, accountability and transparency should be ensured (4) the planning process should be participative and a maximum level of board participation in management affairs should be stipulated.
\end{abstract}

\section{INTRODUCTION}

The rapid and dynamic change in the context of higher education since the 1990s has regenerated interest in developing and sustaining effective university governance structures (Asiimwe and Steyn 2013; Bleiklie 2014; García-Aracil and Palomares-Montero 2010; Ramirez and Tiplic 2014; Trends in Higher Education Governance 2009). The growing challenge for universities to mirror community needs in their processes is forcing them to adopt structures that are more outward looking (Strategy Group 2011; Asiimwe and Steyn 2013). Moreover, effective leadership and management structures are integral to enhancing academic quality and innovation at universities (Marshall et al. 2011). Asiimwe and Steyn (2013), citing Baldwin (2009), emphasise the primacy of governance in fostering quality and innovation at universities. Baldwin (2009) and Asiimwe and Steyn (2013) consider governance to be the glue that binds the components of the university together. Therefore, universities can leverage their challenges and become more responsive to their own academic needs and global community needs by establishing effective governance structures (Baldwin 2009; Strategy Group 2011; Asiimwe and Steyn 2013).
However, to be successful, policy makers and the academia should clearly understand the university governance landscape, the requisite variety of components and how they should be constructed to meet the competing needs (Bleiklie 2014).

Few studies have focused on university governance and its intensely dynamic context in Africa (Kezar 2006; Luescher 2008) and in Uganda in particular. In the context of Uganda, Akodo and Moya (2009) studied corporate governance and financial performance of public universities while Baine (2010) examined the effects of privatisation on gender justice. In contrast, Bisaso (2010) examined organisational responses to public sector changes at Makerere University. From a different perspective, Onsongo (2009) probed the outcomes of affirmative action policies focusing on enhancing access to university education by women in Kenya, Uganda and Tanzania. From the existing literature, it appears that there has been little focus on how Ugandan universities can build and sustain effective governance to meet the challenges of the rapidly changing environment. This study reports on the findings of Asiimwe (2012) in the doctoral thesis "Developing and sustaining effective governance in universities in Uganda”. It seeks 
to answer the critical question: What are the building blocks for effective and sustainable university governance in Uganda?

Howard (2012) argues that the need for development, changing global economic trends, and the demand for highly skilled human capital have placed unparalleled pressure on universities globally and Sub-Saharan African universities in particular to be more responsive. Therefore, universities as centres of knowledge and innovation are challenged to be more flexible and outward looking. Arguably, the nature of the governance in place determines how the university's resources are allocated and competing needs of the institution satisfied (Lapworth 2004; Baldwin 2009). Moreover, universities need to evolve governance structures that are more efficient, accountable, transparent, effective and flexible (Chacha 2001; Asiimwe and Steyn 2013). Such structures should be able to enhance decision making, prioritise and focus university resources on value-adding processes and realise the objectives of the university in its wider context.

Kasozi (2003) argues that Uganda had a robust higher education sector in the 1960s and early 1970s while its premier university, Makerere University, was the regional academic hub. Moreover, Makerere University used to attract the cream of regional academics and students (Bisaso 2010; Asiimwe and Steyn 2013). However, the trend was reversed by poor economic governance, insecurity, political interference and lack of adequate funding (Bisaso 2010). In 1986, there was a new dawn in Ugandan politics, with a new government in place that redefined the educational environment (Ministry of Education and Sports 2001). Consequently, a number of educational reforms were undertaken notably, the liberalisation of the education sector. This involved opening up of admission to university and tertiary institutions to private students, licensing of private universities and institutions of higher learning, establishment of a higher education sector regulatory body, expanding the academic menu, and legislative and administrative reforms (Kasozi 2003; Bisaso 2010). Most relevant to this study are the following: the enactment of the University and Other Tertiary Institutions Act 2001 and the establishment of the National Council for Higher Education (NCHE) as the higher education sector regulator (Asiimwe and Steyn 2013). These two measures pro- vided the right institutional framework for managing higher education institutions in Uganda.

However, in spite of the institutional framework that is in place for governing higher education, it is argued that mere stipulation of the various factors considered part of governance is not suûcient (Fountain 2012). Governance structures such as the governing boards/councils are charged with monitoring and controlling the performance of universities and other tertiary institutions as specified by the University and Other Tertiary Institutions Act 2001 as amended in 2003 (Akodo and Moya 2009). Although boards/councils exist in Uganda, it is startling that the governance record of Uganda's universities is characterised by, inter alia, failure to pay staff salaries, diversion of funds, large-scale expenditure on non-academic programmes, recruitment of low-calibre staff, personalising of offices, embezzlement, lack of transparency and poor accountability builds on five widely (Akodo and Moya 2009; Owoeye and Oyebade 2010). This situation has resulted in Ugandan universities being poorly rated internationally and failing to deliver according to the expectations of their stakeholders (Asiimwe and Steyn 2013), persistent staff and student strikes, legal battles, and acrimonious working relationships between management and workers' associations (Akodo and Moya 2009). Therefore, it is our contention that the existence of governance organs notwithstanding, the structure and interaction of the organs within the governance system of the university are key components in achieving effectiveness.

\section{Conceptual Framework}

Governance relates to decisions that deûne expectations, grant power, or verify performance and consists of a separate process or is part of management or leadership processes (Fountain 2012). It is the foundation of the overall control environment of the organisation and includes internal policies, decision structures, compliance structures and the accountability processes (Fountain 2012). Building effective university governance poses a number of challenges in the global university context. Pivotal to these challenges is how the different components of the governance power structure are glued together and how they exercise their power relative to the objectives of the organisation. In their 
search for an effective model, university scholars, practitioners and policy makers have come up with a number of governance models (Asimiran 2009; Trends in Higher Education Governance 2009; Asiimwe and Steyn 2013). This study builds on five widely acclaimed governance models, namely shared governance, and the collegial, political, corporate and bureaucratic models, to glean scholarly views that provide a theoretical anchor for our arguments.

A shared model of university governance builds on the core values of the organisation (Kezer and Eckel 2004; Shattock 2006; Asiimwe and Steyn 2013). Therefore, governance outcomes are achieved through ensuring transparency, clarity of operations and decision-making, open lines of communication between and among all components and members of the university, accountability, mutual respect and trust. The substructure of the shared model in a university includes four core representative bodies: the university council, the faculty senate, the staff senate and the student governance association. These bodies enable shared responsibility and promote member contributions to the university (Asiimwe 2012). Moreover, Kezer and Eckel (2004) and Shattock (2005) cited in Asiimwe and Steyn (2013) postulate that shared governance mirrors and enriches the principles of mutual respect and trust in the university community. On the other hand, Kogan (2002) and Trakman (2008) offer an alternative model, namely the collegial model. According to Kogan (2003) and Trakman (2008), university governance should be built along the collegiality principles (sharing of authority among colleagues). Therefore, the collegial model should ensure consensus based decisions and enhanced professional authority (Asiimwe and Steyn 2013). The governance culture should foster shared authority, strong professional relationships and mutual respect among members of the community in order to realise collegial expectations (Kezer and Eckel 2004; Cakata 2005).

Altibach (2011) suggests a political model as a governance structure that fosters stakeholder interests since the university is perceived as a collection of competing interest groups that influence decisional processes. Altibach (2011) argues that the political model is anchored in three theoretical sources: the conflict theory (struggle to maximise benefits), the community power theory (power in the hands of different organised interest groups) and the interest group theory (decisional processes focusing on how resources and utility are distributed between individuals and groups). Altibach (2011), Asimiran (2009) and Asiimwe and Steyn (2013) suggest that the governance structure and the decisional culture must take into account the social structure, interest articulation dynamics and the way policies are made and implemented. Altibach (2011) and Asimiran (2009) contend that there is political activism which influences and shapes university performance. Therefore, university governance that loses sight of the political nature of the institution would be less effective in realising the organisation's objectives.

Baird (2007) has described university governance through the lenses of the corporate world. Baird (2007), in postulating the corporate model of university governance, suggests that universities operate in a market-oriented context and should therefore have decisional structures that respond to the world around them. Moreover, Henkel (2000), Baird (2007) and Altibach (2011) contend that the business of the university should mirror community demands. Like other corporations, universities have a duty to account to both internal and external stakeholders. Akodo and Moya (2009) contend that the university board/council and the subordinate governance organs should be able to achieve improved performance, more especially in using the organisation's resources. Therefore, universities should evolve structures that, when well aligned, should foster accountability, responsiveness and ability to maximise stakeholder utility.

According to Asiimwe and Steyn (2013) citing Trakman (2008), university governance may be described as a bureaucratic model. Hall and Symes (2005) argue that the university governance model exhibits characteristics of bureaucracy as propounded by Max Weber, that is, a hierarchy tied to chains of command, defined spans of control, clear channels of communication, predetermined rules and regulations and efficiency maximisation. Managers are regarded as career staff and governance focuses on matters like tenure of office, how staff are appointed and remunerated, a lifestyle that mirrors organisational culture and acceptance of seniority and competency as bases for promotion. Hall and Symes (2005) argue that in bureaucratic governance, initiatives and policy directions come 
from the top strata while implementation of policies is carried out at the lower levels within the guidelines set from above. Ostensibly, this suggests that subordinate governance organs are not involved in the decision making process. It is not the intention of this study to evaluate the effectiveness of the different governance models but to use them to appreciate the general nature of university governance and to identify what elements effective governance should possess and how they should be structured.

Several scholars have argued that the building blocks for effective and sustainable university governance include strong leadership, culture and communication; appropriate governance committee structures; clear accountability mechanisms; working effectively across organisational boundaries; and strategic planning, performance and evaluation (Bartos 2004; Stanton 2007). Allport (2001), Schumacher (2006), Stanton (2007) and Trakman (2008) say that creating strong leadership with properly constructed and empowered leadership organs, a valuebased culture and open and flexible communication channels enhances transparent and committed leadership that leads to achievement of university objectives.

On the other hand, Akodo and Moya (2009) and Fountain (2012) contend that effective and sustainable university governance requires appropriate governance committee structures. These scholars argue that the structures should include committee structures that decentralise power, segregate duties and enhance democratic decision making. The committees should be empowered to take decisions concerning the direction of the university and monitor the performance of the implementation organs. Furthermore, building and sustaining effective university governance requires clear accountability mechanisms (Schutte 2000; Kasozi 2003; Fourie 2003). Accountability increases governance effectiveness in terms of better performance monitoring, transparent leadership, and utilisation of the university's resources to maximise stakeholder utility. These mechanisms should include financial controls that incorporate both internal and external oversight structures and regular performance reports. These will ensure financial propriety and make certain that resources are utilised to meet the competing demands from the university stakeholders.

According to Gumport (2000), Bartos (2004) and Trakman (2008), effective university governance can be enhanced by creating mechanisms that make it possible to work successfully across organisational boundaries. It is argued that a cross-functional labour force with the right attitudes, skills and knowledge to deliver services can be created. This calls for the building of excellent working relationships with both internal and external stakeholders. Proper information flows, community participation, implementation of agreed-upon client charters and accountability mechanisms foster governance effectiveness.

Akodo and Moya (2009), Cloete et al. (2011) and Fountain (2012) argue that to sustain effective governance, there should be mechanisms to ensure comprehensive risk management, compliance and assurance systems. Universities should put management protocols in place to guide decision making, establish committees to audit activities and monitor the implementation of decisions. It is postulated that the above mechanisms enhance the application of principles of sound practice. Moreover, they reduce the risk that the university's resources will be lost and promote stakeholder utility. In such circumstances, therefore, the governance organs should create open, robust, comprehensive and flexible systems to deal with situations that would affect the university's ability to deliver services efficiently and effectively.

According to Kasozi (2003), Shafritz and Russel (2005) and Fourie (2003), strategic planning and performance evaluation institutionalise shared vision, unity of objective (optimality) and prioritisation of resources to meet the most urgent and important goals of the university. Mechanisms for inclusive long-term planning like having a strategic plan, regular holistic performance reviews and circulation of performance reports to stakeholders not only promote accountability but also ensure optimal utilisation of resources. The presence of these features in the university governance processes ensures better performance of governance roles and realisation of the university's objectives. Therefore, as argued by the scholars, university administrators should embed these features when setting up, running and reviewing governance organs.

\section{RESEARCH DESIGN}

The study used a mixed research paradigm combining both quantitative and qualitative approaches that enabled the study to delve deeper into the research problem. The mixed meth- 
ods have particular value when trying to solve a problem in a complex educational context (Viadero 2005). Creswell (2008) in particular argues that "mixed methods research is eminently suited for exploring variations in the construction of meaning of concepts in relation to how respondents for instance make sense of their experiences or report on attitudes in interviews or questionnaire respectively". Such a systematic inquiry into participants' variations of social considerations of meaning in the interviews and the survey of respondents in the questionnaires validates the research instruments and also produces supplementary results which enrich the overall findings in the study (Brown 2011). Data were collected in two phases; phase 1 for the quantitative design and phase 2 for the qualitative design.

In phase 1 , quantitative data were collected from university administrators, including the vice-chancellors, registrars, deans, heads of department, academic staff and students (Viadero 2005). The quantitative instruments on a fivepoint Likert scale were used to measure, among others, the building blocks for effective and sustainable university governance in the sampled universities. The quantitative data collection preceded the qualitative phase in order to explore and test variations (Brown 2011). The study leant towards qualitative design but was complemented and supplemented by the quantitative method. The qualitative data in phase 2 investigated, described and identified relationships between events and meanings to increase understanding of the phenomena. Phase 2 utilised interviews and focus group discussions using interview schedules and discussion guides to obtain data from the participants. Field observations were also carried out where the administrators, students and other staff members at these universities were observed. The approach emphasised the views and experiences which involved subjective and bias elements as perceived by the participants in their life worlds. The research questions in the study were therefore concerned with the way in which governance took place at the universities.

For the purposes of this study, two public universities (A and $\mathrm{E}$ ) and three private universities (B, C and D) in Uganda were selected. The universities were selected purposively to obtain information from public and private universities in order to compare their governance practices. Respondents in the quantitative phase include the vice-chancellors, the registrars, deans and a board member from each university. The number of respondents in the different groups from each university depended on the size of the university. The questionnaire design was informed by reflections from the literature review, the theoretical orientation and the conceptual framework. It aimed at capturing the gist of the study objective so that respondents would answer specific research questions and provide a logical flow of responses. The questionnaire was piloted at two universities that were not part of the study to test its feasibility, and was adapted according to the recommendations of the respondents.

Purposive sampling in the qualitative phase was done by identifying influential individuals whose work was related to the university's governance or whose activities influenced governance at the university (see Table 1). Careful consideration was given to university officers, especially the administrators who had served at these universities for more than two years. Semistructured individual interviews were then conducted with the top administrators, including the vice-chancellors and the registrars, both to obtain clearly defined information and to allow participants the opportunity to respond. The interview guide was also structured to reflect those results from the quantitative phase that required clarity. Focus group interviews were conducted with the different groups of participants such as the deans, academic staff and students.

Table 1: Participants in the qualitative phase

\begin{tabular}{llr}
\hline $\begin{array}{l}\text { Participant } \\
\text { category }\end{array}$ & University & $\begin{array}{c}\text { Number of } \\
\text { participants }\end{array}$ \\
\hline Heads of Department & A & 5 \\
& B & 4 \\
& C & 3 \\
Dcademic Staff & E & 2 \\
& Subtotal & 1 \\
& A & 15 \\
B & 7 \\
Students & C & 6 \\
& D & 4 \\
& E & 5 \\
& Subtotal & 3 \\
& A & 25 \\
& B & 15 \\
& C & 10 \\
& D & 5 \\
& E & 5 \\
& Subtotal & 5 \\
& Overall total & 80 \\
\hline
\end{tabular}


Before the quantitative data analysis, the data were checked for mistakes to avoid the distortion of the results of the statistical analysis. The responses were then coded and analysed using the Statistical Package for the Social Sciences (SPSS). Descriptive statistics, including tallying of frequencies, calculation of percentages and central tendency summaries were used for data analysis. Regression analysis was done to establish the relationships between the different variables. During qualitative data analysis, all the data from interviews, field notes and relevant documents were first reviewed in general to get an overall impression of the data and then coded for analysis according to the method of qualitative data analysis described by Creswell (2008). During this process, patterns of data were identified, and descriptions were developed and interpreted to generate meaning. A literature control was conducted to identify similarities and differences between this study and previous research, as well as the contribution made by this study. This gave the data gathered structure and allowed for triangulation between the various research instruments used in the study. Cross-checking was done by using different interviewees' responses, university publications, including university constitutions, rules and regulations. Member-checking was also done to ensure accuracy of understanding and interpretation. Compliance with ethical issues was achieved by seeking the consent of respondents and participants to ensure privacy and confidentiality of their identity.

\section{RESULTS AND DISCUSSION}

Uganda has seven public universities and around 24 private universities across the five regions. As mentioned previously, this study focused on two public and three private universities in the central region of Uganda to identify the building blocks for effective and sustainable university governance at Ugandan universities. In phase 1, the key constructs relating to building blocks for effective and sustainable university governance were used to obtain respondent perspectives (see Table 2).

Results from phase 2 revealed that participants held different views on the type and impact of building blocks for effective and sustainable university governance in Uganda. In general, participants echoed the views of respon- dents in phase 1 that the key building blocks for effective and sustainable university governance in Uganda were characteristics of the university board, quality of the structure of the board, management involvement in university governance and participation of the board. The data analysis in phase 2 revealed that participants held differing views on the building blocks and how they sustain university governance. The following main categories emerged from the data: professional competence of the board, quality of governance structures, participatory planning process and board participation in management.

\section{Professional Competence of Board Members}

The findings reflected in Table 2 indicated that professional competence of board members was important in building effective university governance. From the descriptive statistics, there was an agreement amongst the respondents that professional competence of board members was critical in ensuring effective governance. The analysis of board performance is given in Table 2 .

Table 2: Descriptive statistics of the characteristics of university boards

\begin{tabular}{lccc}
\hline & $N$ & Mean & $\begin{array}{c}\text { Stan- } \\
\text { dard } \\
\text { devia- } \\
\text { tion }\end{array}$ \\
\hline $\begin{array}{l}\text { Board members have } \\
\text { enough functional } \\
\text { backgrounds }\end{array}$ & 98 & 4.02 & .963 \\
$\begin{array}{l}\text { Qualifications and experi- } \\
\text { ence are set out in }\end{array}$ & 98 & 3.94 & 1.044 \\
$\quad \begin{array}{l}\text { writing } \\
\begin{array}{l}\text { There is an ethical } \\
\text { corporate culture }\end{array} \\
\begin{array}{l}\text { Enough tenure is given } \\
\text { to the board }\end{array}\end{array}$ 98 & 3.69 & 1.196 \\
$\begin{array}{l}\text { They have sufficient funct- } \\
\text { ional backgrounds }\end{array}$ & 98 & 3.95 & 1.161 \\
$\begin{array}{l}\text { The board acts indepen- } \\
\text { dently without inter- } \\
\text { ference }\end{array}$ & 98 & 3.55 & 1.132 \\
\begin{tabular}{l} 
They are very competent \\
\hline
\end{tabular} & 98 & 4.15 & .978 \\
\hline
\end{tabular}

Results with mean scores above 3.51 and corroborated by participant interviews and focus group discussions show that universities whose board members had a background in areas such as accountancy, finance, public policy or technology were more effective than those that did not. Respondents stated that board 
effectiveness increased with longer tenure of office (enough time to plan and implement decisions), ethical corporate culture (which promoted communication, transparency and accountability), as reflected by the mean score of 4.33 , training (to improve members' awareness of their roles, foster strategic planning skills and strengthen decisional capabilities) and independence in decision making. This confirms the postulations of Stanton (2007) on the features of an effective university board. However, discussions with focus groups showed scepticism about the qualifications of board members, especially at private universities. Participants indicated that some board members were not given orientation and induction and this was creating a vacuum in university governance leading to inefficiency. In this regard, an administrator from university (D) observed, "with interference of the top management we don't know whether members are qualified or not and there are many factors included when recruiting which I cannot mention now".

The findings are in agreement with the contention of Lombardi et al. (2002), Bartos (2004) and Stanton (2007), that effective governance can be built through having boards with enough functional background, tenure, ethical corporate culture and independence. Gallagher (2001) concurs with Bartos (2004) and Stanton (2007) that the above factors increase efficiency and compliance, both factors which are critical in meeting governance challenges. These factors ensure that boards should be strong enough to establish, operate and superintend sound governance systems. Professional competence is therefore one of the cornerstones of strong leadership in a university (Bradley 2003; Baird 2007; Stanton 2007). University governance is consequently more effective when boards with desirable competences are established in the university governance structures. When selecting board members, attention must be paid to factors such as level of experience, relevant professional training and the moral standing of the members (Kogan 2002; Trakman 2008). According to Asimiran (2009), these attributes have to be strengthened by effective orientation and training in key areas of university governance such as accountability, planning and performance evaluation. In addition, the board's term of office has to be of sufficient length to enable members to formulate plans and implement them.
A term of office ranging from three to five years would be enough to plan, implement and manage university programmes effectively, which would enhance the quality of governance structures.

\section{Quality of Governance Structures}

Quality of governance structures emerged as one of the important building blocks for effective university governance in Uganda. The findings reflected in Table 3 indicate that the quality of governance structures influences the degree of efficiency and effectiveness of the institution. The quality of governance determines the quality of university governance as observed by Altibach (2011). The quality of governance structure is analysed in Table 3 with the aid of descriptive statistics.

Table 3: Descriptive statistics reflecting quality of governance structure

\begin{tabular}{|c|c|c|c|}
\hline & $N$ & Mean & $\begin{array}{l}\text { Stan- } \\
\text { dard } \\
\text { devia- } \\
\text { tion }\end{array}$ \\
\hline $\begin{array}{l}\text { There is a three-tier } \\
\text { evaluation process }\end{array}$ & 98 & 3.68 & 1.061 \\
\hline $\begin{array}{l}\text { Evaluation is done at } \\
\text { least once a year }\end{array}$ & 98 & 3.92 & 1.190 \\
\hline $\begin{array}{l}\text { There is strong stakeholder } \\
\text { involvement }\end{array}$ & 98 & 3.56 & 1.227 \\
\hline $\begin{array}{l}\text { Appropriate governance } \\
\text { structure }\end{array}$ & 98 & 3.60 & 1.182 \\
\hline $\begin{array}{l}\text { There is an independent } \\
\text { audit committee }\end{array}$ & 98 & 4.21 & .987 \\
\hline $\begin{array}{l}\text { There is an independent } \\
\text { compensation committee }\end{array}$ & 98 & 4.40 & .714 \\
\hline $\begin{array}{l}\text { There is an independent } \\
\text { nominations committee }\end{array}$ & 98 & 4.05 & .709 \\
\hline $\begin{array}{l}\text { Top management leadership } \\
\text { is adequate }\end{array}$ & 98 & 4.42 & 1.201 \\
\hline $\begin{array}{l}\text { There is a free flow of } \\
\text { information between } \\
\text { governance structures }\end{array}$ & 98 & 4.21 & 1.302 \\
\hline $\begin{array}{l}\text { There is formality on all } \\
\text { committee proceedings }\end{array}$ & 98 & 4.55 & .875 \\
\hline
\end{tabular}

Results with a mean score above 3.68 indicate that respondents agreed that governance improved where board and senate did three tier evaluation processes, that is, where evaluation involved three stages including various officers of the university. In addition, better governance was associated with stakeholders' involvement in decisional processes; strong committee structures, along with increased transparency; seg- 
regation of duties and accountability; well-established performance evaluation and monitoring mechanisms with regular reporting and feedback; internal controls; and proper financial behaviour. Moreover, where management leadership was adequate, there was a free flow of information between governance structures and formal committees were in place the quality of governance improved.

The results, as corroborated by participant interviews and focus group discussions, emphasised transparency, accountability, financial propriety, academic freedom and autonomy as tenets that promoted quality governance. The primacy of the quality of governance structures in promoting effectiveness is supported by authors such as Coaldrake et al. (2005) and Altibach (2011), who argue that appropriate governance structures allow easy decision making in universities and hence effective governance. However, the views expressed in focus group discussions showed that at some private universities structures were not organised. Heads of department from universities (C) and (D) indicated, "We are not involved in policy making and we are not happy of this." As postulated by Asimiran (2009), effective governance structures emphasise academic freedom and autonomy, enhance performance in terms of added value for students, and ensure public accountability, reporting and transparency. Similar sentiments were expressed by participants from University (B), who indicated, "We lack autonomy and we do not make decisions, the majority of decisions are made by university top management and we do not exercise our expectations.” Therefore, to build effective university governance, it is necessary that there should be a board separate from the senate; specialised committees like audit, nomination and compensation committees; and strong stakeholder involvement. Universities should ensure that governance structures segregate roles to create the necessary checks and balances.

The senate should have autonomy over academic programming and should ensure that the academic menu provided by the university meets stakeholder expectations. The compensation committee should ensure that employees of the university are properly remunerated. The recruitment committee must ensure that the university has the right human resources to arrange its activities so as to meet the desired objectives. The opposite appears to be true at University (D), where the academic staff complained. A staff member said: "We do not follow the strategic plan because our leaders are not articulate and the majority of the workers are not involved in taking decisions. The mission and vision are not known by most members and that stake holders are not involved in contributing to the accomplishment of the university plan and structures are not clear". Accountability for decisions and resource utilisation should be built into the reporting mechanisms of the university. However, one participant from University (B) indicated, "The board by nature and rules set by governance structure, is supposed to set directions, and analyse strategic plans. I have never seen or heard of a strategic plan.” This explains why many universities have no road maps for development and meeting stakeholder expectations. The findings by Trakman (2008) and Altibach (2011) indicate that internal controls and external oversight procedures must be created to enhance transparency and accountability. University $(\mathrm{C})$ also complained, "The problem is that management does not want to be open in everything. They delay information, hide information, and work is delayed." Lack of information not only delays work but leads to problems of coordination. The contributions of various parts of the university cannot be combined in a coherent/efficient form that meets the needs of the stakeholders.

At board level, oversight committees like the audit committee must be set up to review organisational efficiency and effectiveness in meeting stakeholder needs. In decisional and operational processes, emphasis should be placed on openness, trust and accountability. Heads of department from Universities (C) and (D) had similar issues, "We are not aware of the rules of the university and have not read them, we just talk as members and after the meeting we are paid." Although there are concerns that some critical aspects of building effective governance are not prioritised, participants did appreciate the importance of having such components at their universities. By and large, the quality of the governance structure is determined inter alia by the quality of the members, the degree of autonomy enjoyed by the committees, the ethical culture cultivated among members and between management and governance committees, effectiveness of communication, clarity of roles 
and a participatory planning process (Shutte 2000; Stanton 2007).

\section{Participatory Planning Process}

According to Gayle et al. (2003), the success of an institution depends on good leadership, where managers should walk the talk and model good governance behaviours to achieving governance goals. The analysis in Table 4 shows university administrators doing the job well.

Table 4: Descriptive statistics of involvement of the university management

\begin{tabular}{lccc}
\hline & $N$ & Mean & $\begin{array}{l}\text { Stan- } \\
\text { dard } \\
\text { devia- } \\
\text { tion }\end{array}$ \\
\hline $\begin{array}{l}\text { The University has a five- } \\
\text { year strategic plan }\end{array}$ & 98 & 3.90 & 1.180 \\
$\begin{array}{l}\text { They clearly reflect our } \\
\text { strategic plan decisions }\end{array}$ & 98 & 3.97 & 1.516 \\
$\begin{array}{l}\text { The University Manage- } \\
\text { ment gives direction }\end{array}$ & 98 & 3.89 & 1.566 \\
$\begin{array}{l}\text { Management ensures that } \\
\text { accomplishments are well } \\
\text { communicated }\end{array}$ & 98 & 3.95 & 1.205 \\
$\begin{array}{l}\text { Management has ensured } \\
\text { that members and stake- } \\
\text { holders have received } \\
\text { reports }\end{array}$ & 98 & 3.99 & 1.516 \\
\hline
\end{tabular}

Respondents indicated (mean score 3.90) that universities with strategic plans were able to focus their resources on the priority areas of the university. Moreover, it was established that effective strategic plans were those that involved key stakeholders, including administrators; spelled out the university goals, activities and resources; ensured that departmental and unit plans were congruent with master plans and were effectively communicated to the implementing units and consistently followed by the managers. The findings therefore indicate that a participatory planning process is an important building block in effective university governance. Results from participant interviews and focus group discussions indicated that consistent communication and clarification of organisational goals were critical to enhancing effective governance. The findings were supported by the studies of Kasozi (2003) and Bartos (2004) on the importance of joint planning; Schumacher (2006) on the relationship between planning and goal achievement; Stanton (2007) on consistent communication and effective governance and Stanton (2007) on stakeholder involvement and improvement in governance. Interviews with key informants indicated great appreciation of participation in university management as integral to meeting stakeholder needs. This is exemplified by the views of one participant from University (D), "The University should have participative planning if there is to be goal congruence and satisfaction of our varied stakeholders." An administrator from university (B) indicated that, "Policies and rules should be determined to direct university affairs more especially planning." On the other hand, it was established that lack of participation in decision making, top-down decisional processes, failure to share organisational objectives between managers and subordinates and poor communication impeded effective governance. These findings were supported by Dooley (2003), Bartos (2004) and Sporn (2008). Poor communication and limited participation existed which demoralised people who were expected to participate. This is borne out by an administrator from University (C), who lamented that, "The University had several meetings when am not aware yet am supposed to attend and it seems, I am not the only one affected. Such practices deny us our right to take part in decision making and create the necessary change we would like to see." It is clear from the foregoing that poor communication limits participation and affects governance. To build and sustain effective governance, it is necessary that there should be clear and unfettered channels of communication. Universities need to establish mechanisms for participatory planning where stakeholders are involved and informed, staff is empowered to make decisions, and clear policies, rules and decisional processes that direct university affairs are set. This is borne out by an administrator from University (D), who underscored the primacy of stakeholder involvement in decision making and therefore promoting effective governance. He indicated that, "Stakeholders help us in setting joint strategic priorities and decisions through feedback and I think we cannot work without them because they are sources of everything and they mean a lot to us." Universities need to establish planning committees that draw membership across functional areas of the organisation to ensure participation. Similar feelings were evi- 
dent at University (E), where an administrator indicated, "I accept stakeholders help in achieving a key cultural change in terms of interaction between the scientific arena, community industry and the government entities and relationships help the universities to get feedback, guidance and outcome”. Internally, functional plans must be originated at the functional level and developed by the staff within the specified unit according to the policy guidelines followed by the university.

To ensure participation while maintaining goal congruence, strategic planning objectives should be clearly defined so that they can be cascaded down to functional levels to enable lower levels to develop plans that fit into the overall university master plan. Each functional area should agree on its planned activities (Pierre 2000; Bartos 2004). As is confirmed by Stanton (2006) and Trakman (2008), managers have to secure commitment and ownership from their members to ensure smooth implementation. Cross-functional planning meetings are necessary to agree on the consolidated plans before they are approved by the board. The board should have ample time to discuss the plan and convince themselves that such a plan in its current form would meet stakeholders' needs. In addition, members involved in the planning process need autonomy to make decisions concerning resource acquisition and disposal at their respective levels to make the process more effective (Hall and Symes 2005; Altibach 2011). The approved plan should be communicated to the stakeholders to enable them to understand their role in ensuring its success and to help in monitoring and evaluation, enhancing transparency and promoting accountability. Client charters which communicate to the stakeholders how the university is committed to meeting their needs and what role stakeholders should play in realising the university's obligations to them can be derived from the plan. This process should be capable of increasing participation, openness, accountability and stakeholder utility (Trakman 2008).

\section{Board Participation in Management}

Du Preez (2000), Shafritz and Russel (2005) and Fourie (2003) argue that the board's guidance in terms of participation ensures that their constituents are satisfied and fully aware of what is happening at the university. The descriptive statistics in Table 5 analyse agreement amongst the respondents and board participation.

Table 5: Descriptive statistics on board participation in management

\begin{tabular}{|c|c|c|c|}
\hline & $N$ & Mean & $\begin{array}{l}\text { Stan- } \\
\text { dard } \\
\text { devia- } \\
\text { tion }\end{array}$ \\
\hline $\begin{array}{l}\text { All board members are } \\
\text { aware of what is expec- } \\
\text { ted of them }\end{array}$ & 98 & 3.92 & 1.146 \\
\hline $\begin{array}{l}\text { The agenda of board } \\
\text { meetings is well planned }\end{array}$ & 98 & 3.94 & 1.545 \\
\hline $\begin{array}{l}\text { All members come to } \\
\text { meetings well prepared }\end{array}$ & 98 & 3.90 & 1.570 \\
\hline $\begin{array}{l}\text { All board members receive } \\
\text { written reports well in } \\
\text { advance }\end{array}$ & 98 & 3.88 & 1.286 \\
\hline $\begin{array}{l}\text { All board members partici- } \\
\text { pate in important board } \\
\text { discussions }\end{array}$ & 98 & 3.89 & 1.566 \\
\hline $\begin{array}{l}\text { All decisions made are sup- } \\
\text { ported by different } \\
\text { managers }\end{array}$ & 98 & 3.89 & 1.566 \\
\hline The board now recruits staff & 98 & 4.16 & 1.173 \\
\hline $\begin{array}{l}\text { The board has planned and } \\
\text { led the orientation process }\end{array}$ & 98 & 3.90 & 1.482 \\
\hline $\begin{array}{l}\text { The board has a plan for } \\
\text { director education }\end{array}$ & 98 & 3.90 & 1.214 \\
\hline
\end{tabular}

The findings of the study indicated that board members who were aware of their duties, familiar with university by-laws and regularly informed about what is happening at the university supported the decisions made and promoted the work of the university. Results with a mean score of 3.92 indicated that universities with board members that planned for the board meetings, participated in the recruitment of key administrators and had clarity on board roles and processes enhanced governance. It was observed that such boards are effective in analysing university needs, allocating resources, evaluating performance and ensuring that university staff structures are occupied by competent administrators. However, participants from universities (C) and (D) were suspicious. "We are not sure of what these members do in meetings because we have never seen any action. Some of the members come to sign the attendance and nothing else. Therefore, their participation in management is not genuine. We would see improvement in the way the university is run if they were actually participating.” Although 
the staff members are aware of the importance of board participation in ensuring effective governance, pseudo participation affected the board's ability to improve governance. One of the factors that affected participation in management was role ambiguity. Results from participant interviews and focus group discussions strengthened this postulation by suggesting that in the university structure and participative management the roles of the board and the senate should be clearly segregated to avoid role confusion. Where there is clarity and autonomy, as one administrator at University (E) observed, "We have autonomy and we make decisions. At least we participate in all decisions concerning the board and most of the university decisions are made by us and we are free to communicate." This situation enhances complementarity between the functions of the board and the senate, resulting in better governance. Empirical studies by Fourie (2003), Shafritz and Russel (2005) and Schumacher (2006) support the findings and emphasise the role of board participation in management and its impact on ensuring effective governance.

From the foregoing, it appears that to enhance board participation the roles should be clear, members must meet regularly at least monthly, they should be provided with progress reports on university activities and management should update members during board meetings about the progress of implemented board decisions. Moreover, board autonomy needs to be maintained for effective strategic planning and policy direction. To deepen board participation in management processes more meaningfully, board members should participate in some dayto-day activities on an advisory basis like during staff evaluation, performance monitoring, evaluation, and management meetings (Dooley 2003; Kezar and Eckel 2004; Altibach 2011). There should be smooth two-way communication between the board and management. Involvement of the board should be introduced cautiously to avoid role conflict, however. Board participation adds more value when members are oriented to enable them to conduct themselves within the confines of their structural jurisdiction.

\section{CONCLUSION}

The study indicated that Ugandan universities could build and sustain effective governance if the critical building blocks are adhered to. It revealed that the building blocks for effective governance included professional competence of board members, quality of governance structures, a participatory planning process and board participation in management. In addition, effective communication came out as the common adhesive for ensuring that the building blocks lead to better governance.

\section{RECOMMENDATIONS}

The findings revealed that to build and sustain effective governance at universities, the principles of best practice should be observed. These recommendations provide organisational development practitioners in higher education, university administrators and those involved in university governance with the principles of best practice when establishing, running or reviewing university governance. The recommendations include:

- University boards should be composed of members with an appropriate level of professional competence related to governance. To enable board members to perform their governance roles better, they should be trained in relevant skills like planning, communication, accountability and decision making. In addition, they should be engaged for a period of time that allows them to plan and implement decisions.

- Universities should create appropriate governance structures where roles are segregated among the various committees to create the necessary checks and balances. There should be an appropriate quality of membership on the committees, an adequate degree of autonomy to allow members to make decisions, an emphasis on ethics in the performance of their duties, effective communication and clarity of roles.

- To ensure ownership of plans, accountability and transparency, the planning process should be participative. The board should set overall goals and communicate them to lower level units, which should develop their functional plans. Cross-functional meetings to harmonise plans are necessary. Effective governance will be achieved when universities establish mechanisms for participatory planning where stakeholders are involved and informed, staff empowered to make decisions, clear policies are put in place and 
rules and decisional processes are established that direct university affairs.

- A mechanism for board participation in management affairs should be devised. Members need to participate in activities like planning, staff recruitment, and performance monitoring and evaluation. Two-way lines of communication should be maintained for effective board participation. Moreover, board members must be oriented to enable them to conduct themselves within the confines of their structural jurisdiction.

\section{REFERENCES}

Akodo R, Moya M 2009. Corporate Governance and Financial Performance of Public Universities in Uganda. From $<$ http://www.ahero.uwc.ac.za/index. php.> (Retrieved on 15 April 2013).

Allport C 2001. University Governance Plenary on University Governance in the $21^{\text {st }}$ Century. Macquance Graduate Management. From <http:// www.educationstateUniversity.com.> (Retrieved on 15 April 2013)

Altibach P 2011. The past, present and future of the research university. In: P Altibach, J Salmi (Eds.): The Road to Academic Excellence: The Making of World-Class Research Universities. Washington: The World Bank, pp. 11-32.

Asiimwe S 2012. Developing and Sustaining Effective Governance of Universities in Uganda. Thesis, Unpublished. South Africa: University of South Africa.

Asiimwe S, Steyn GM 2013. Obstacles hindering the effective governance of Universities in Uganda. $J$ Soc Sci, 34(1): 17-27.

Asimiran SB 2009. Governance of Public Universities in Malaysia. PhD Thesis, Unpublished. Malaysia: University of Malaya.

Baine EMM 2010. Privatisation of higher education in Uganda and the global gender justice ideal: Uneasy bedfellows? Educational Review, 62(3): 315-328.

Baird J 2007. Taking it on board: Quality findings for higher education governance. Higher Education Research and Development, 26(1): 101-115.

Baldwin JF 2009. Current challenges in higher education administration and management. Perspectives: Policy and Practice in Higher Education, 13(4): 93-97.

Bartos S 2004. Public Sector Governance Australia. Sydney: CCH.

Bisaso R 2010. Organisational responses to public sector reforms in higher education in Uganda: A case study of Makerere University. Journal of Higher Education Policy and Management, 32(4): 343351.

Bleiklie I 2014. Comparing university organizations across boundaries. Higher Education, 67: 381-391.

Bradley D 2003. University Governance -Governing What? Business Higher Education. Round Table Conference on University Governance. From <http:/ /www.c/est.gov.> (Retrieved on 5 May 2013).
Brown R 2011. What do we do about university governance? Perspectives: Policy and Practice in Higher Education, 15(2): 53-58.

Cakata Z 2005. The African University in the $21^{\text {st }}$ Century. South African Journal of Higher Education 19. Special Theme Issue, 2005.

Chacha NC 2001. Higher Education in Africa: Emerging Issues. Nairobi, Kenya: Printers. Cloete N, Bailey T, Bunting I, Maassen P 2011. Universities and Economic Development in Africa. Wynberg, Cape Town: Centre for Higher Education Transformation (CHET).

Coaldrake PL, Stedman L, Little P 2003. Australia's University Governance. From <http: //www. bankingaustralia’sfuturegov.> (Retrieved on 5 May 2013).

Creswell JW 2008. Mixed Research Methods in Education, A Power Point Presentation at Nelson Mandela University, $17^{\text {th }}$ October, 2008. From <http:// www.nmmu.ac.za/documents/education/South\% 20Africa\%20-\%20Nelson\%20Mandela\%20-\%20 Mixed\%20Methods\%20Research.pdf.> (Retrieved on 20 May 2013).

Creswell JW 2008. Educational Research: Planning, Conducting and Evaluating Quantitative and Qualitative Research. $3^{\text {rd }}$ Edition. Columbus, OH: Pearson.

Dooley H 2003. Thematic Analysis: The Role of Academic Boards in University Governance. Australia Meritus Quality Agency.

Du Preez N 2000. Uniform Teasing Norms and Standards. The Journal of the Institute for Public Finance and Auditing, March 2000.

Fountain L 2012. The Walls of Corporate Governance. Fountain GRC LLC.

Fourie DJ 2003. The application of good governance in public financial management. Journal of Public Administration, 41(22).

Gallagher S 2001. Changing Environment for University Governance. From <http://www. backing australiafuture. gov.au/publication.> (Retrieved on 10 April 2013).

García-Aracil A, Palomares-Montero D 2010. Examining benchmark indicator systems for the evaluation of higher education institutions. Higher Education, 60(2): 217-234.

Gayle DJ, Tewarie B, White AQ Jr. 2003. Governance in the Twenty-first Century University: Approaches to effective leadership and Strategic Movement. ASHE-ERIC Higher Education Report, 30(1). San Francisco: Jossey Bass/John Wiley.

Gumport PJ 2000. Academic restructuring: Organisational change and institutional imperatives. Higher Education, 39: 67-91.

Hall M, Symes A 2005. South African Higher Education; the first decade of democracy: From comparative governance to conditional autonomy: Studies in Higher Education, 30(2): 199-212.

Henkel M 2000. Academic identities and policy change in higher education. Higher Education Policy Series 46. London: Jessica Kingsley. Higher Education Management and Policy, 15(2): 135-163.

Howard A 2012. Towards a Global Knowledge Economy: Recent Achievements and Challenges. From $<$ http://www.knowledge-economy.net/.../H.\% 
20ALPER\%20-20Towards\%20a\%20 Global \%20 Knowledge\%20Economy.pdf.> (Retrieved on 10 March 2013).

Kasozi AB 2003. University Education in Uganda: Challenges and Opportunities for Reform. Kampala: Fountain.

Kezar AJ 2006. Rethinking public higher education governing board's performance: Results of a national study of governance boards in the United States. The Journal of Higher Education, 77(6): 986-1007.

Kezar AJ, Eckel PD 2004. Meeting today’s governance challenges: A synthesis of the literature and examination of a future agenda for scholarship. The Journal of Higher Education, 75(4): 371-399.

Kogan M 2002. The role of different groups in policymaking and implementation. Institutional policies and policymaking. In: PR Trowle (Ed.): Higher Education Policy and Institutional Change. Intentions and Outcomes in Turbulent Environments. Buckingham: The Society for Research into Higher Education and Open University, pp. 46-63.

Lapworth S 2004. Arresting decline in shared governance: Towards a flexible model of academic participation. Higher Education Quarterly, 58(4): 299314.

Lombardi JV, Craig, DD, Capaldi, ED Gaten DS 2002. University Organisation, Governance and Competitiveness: The Top American Research Universities. Annual Report from the Lombardi Program on Measuring University Performance. Cambridge University Press.

Luescher TM 2008. Student Governance in Transition: University Democratisation and Managerialism a Governance Approach to the Study of Student Politics; the case of the University of Cape Town.

Marshall SJ, Sorrel J, Cameron A, Bosanquet A, Thomas S 2011. Leading and managing learning and teaching in higher education. Higher Education Research and Development, 30(2): 87-103.

National Council for Higher Education [NCHE] 2010. The State of Higher Education and Training in Uganda 2010: A Report on Higher Education Delivery and Institutions. From <www.unche.or.ug.> (Retrieved on 15 April 2013).

Onsongo J 2009. Affirmative action, gender equity and university admissions - Kenya, Uganda and Tanzania. London Review of Education, 7(1): 71-81.
Owoeye JS, Oyebade SA 2010. Higher Education Research in Uganda: Problems and Prospects. From <http://www3.airweb.org/images/herpnet_v2_ no2. pdf.> (Retrieved on 20 April 2013).

Pierre J (Ed.) 2000. Debating Governance. Oxford: Oxford University Press.

Ramirez FO, Tiplic D 2014. In pursuit of excellence? Discursive patterns in European higher education research. Higher Education, 67: 439-455.

Shafritz JM, Russel EW 2005. Introducing Public Administration. New York: Longman.

Schumacher S 2006. Establishing an Effective Compliance Programme, Compliance Risk Management and the Role of General Counsel. Minnepolis, Minnesota: University of Minnesota, P. 208.

Schutte FG 2000. Integrated Management Systems Strategy Foundation and Implementation. Shattock M 2006. Managing Good Governance in Higher Education. London: Open University Press.

Sporn L 2008. Universities and Structures. From <http:/ /www.calstate.> (Retrieved on 20 April 2013).

Stanton M 2007. Building confident organisation Looking forward looking backward. Public Administration Today. Issue II: April-June 2007, Institute of Public Administration.

Strategy Group 2011. National Strategy for Higher Education to 2030, Dublin, Report of the Strategy Group January 2011. From <http://www. click. infospace.com/ClickHandler.ashx?du=www. hea.ie\%2ffiles\%2ffiles\% 2fDES_Higher_E d_Main_ Report.pdfandru=http \%3a \%2f\%2 fwww. hea.ie\% 2ffiles\%2ffiles\%2fDES.> (Retrieved on 20 April 2013).

Trakman L 2008. Modeling University Governance. University of South Wales Faculty of Law, Research Series 209.

Trends in Higher Education Governance 1 July 2009. University World News, 01 July, Issue 1. From <http:// www.universityworldnews.com/article. php? Story $=200906222139424$. $>$ (Retrieved on 5 May 2013).

Viadero D 2005. 'Mixed Methods' Research Examined, American Psychology Association, Vol. 24, Issue 20, Pg 1, 20. From <http://www.apa.org/ed/schools/ cpse/publications/mix-methods.pdf.> (Retrieved on 20 April 2013). 